\title{
Shallow core drilling and petroleum geology related field work in East and North-East Greenland 2008
}

\author{
Jørgen A. Bojesen-Koefoed, Morten Bjerager and Stefan Piasecki
}

In recent years, both the petroleum industry and government research institutions have shown renewed interest in the petroleum potential of the High Arctic. At the same time, a range of activities are taking place, aimed at defining national borders in the Arctic Ocean following ratification of article 76 of the United Nations Convention on the Law of the Sea (UNCLOS). Parallel to the general upsurge in data acquisition activities, the United States Geological Survey has carried out a Circum-Arctic Resource Appraisal (CARA), which for North-East Greenland was published in 2007. This assessment indicated that a significant petroleum exploration potential exists on the North-East Greenland shelf, in particular in the Danmarkshavn Basin and the North Danmarkshavn Salt Province (Fig. 1). The estimated potential amounts to 31 billion barrels of oil equivalents, principally in the form of natural gas. For comparison, this roughly corresponds to one third of the original reserve of the North Sea basins. The geology of the Danmarkshavn Basin and offshore areas farther to the north is only known in broad outline, since no wells have been drilled and only reconnaissance geophysical data are available. Moreover, the extensive ice cover and the overall hostile climate of the region pose significant logistical and technical challenges to data acquisition. Clearly, this emphasises the importance of analogue studies based on the much better known geology of the onshore basins in East and North-East Greenland. In 2007/2008, the Geological Survey of Denmark and Greenland (GEUS) launched a major petroleum industry-sponsored project with the objective of updating and expanding our current understanding of the petroleum geology of East and North-East Greenland. The project is planned to continue for the next four to five years, and includes compilation of relevant existing data in the form of a geographic information system (GIS) product, supplemented by new data obtained from shallow core drilling and new field work. Below we give a brief overview of a range of field activities that took place in East and North-East Greenland in the summer of 2008.

\section{Shallow core drilling in Jameson Land}

The objective of the drilling was to recover core material from the Upper Jurassic organic-rich shale of the Katedralen Member (Hareelv Formation) to obtain a reference section of

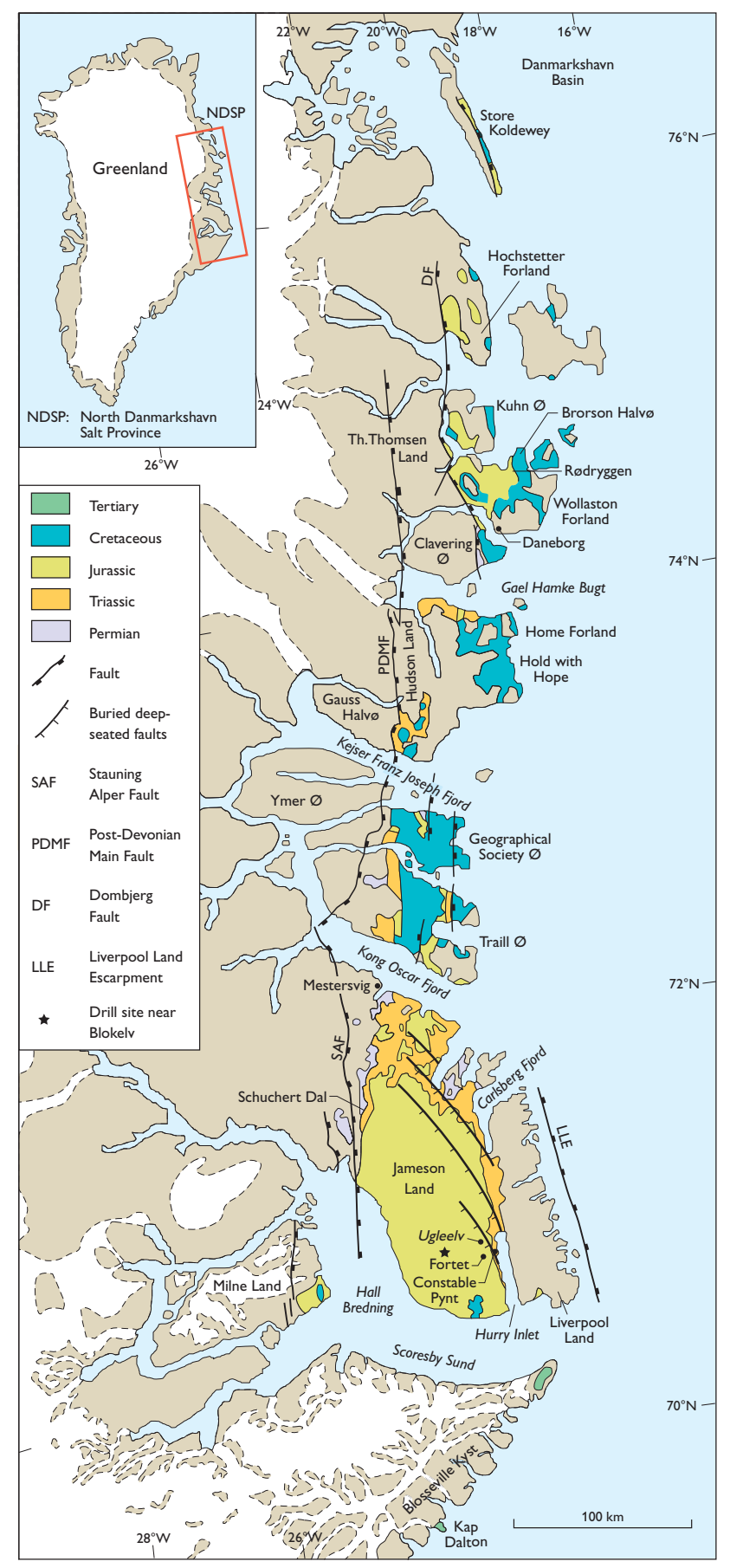

Fig. 1. Map of East and North-East Greenland, showing the distribution of Permian to Neogene sedimentary rocks and the location of place names mentioned in the text. NDSP: North Danmarkshavn Salt Basin. 


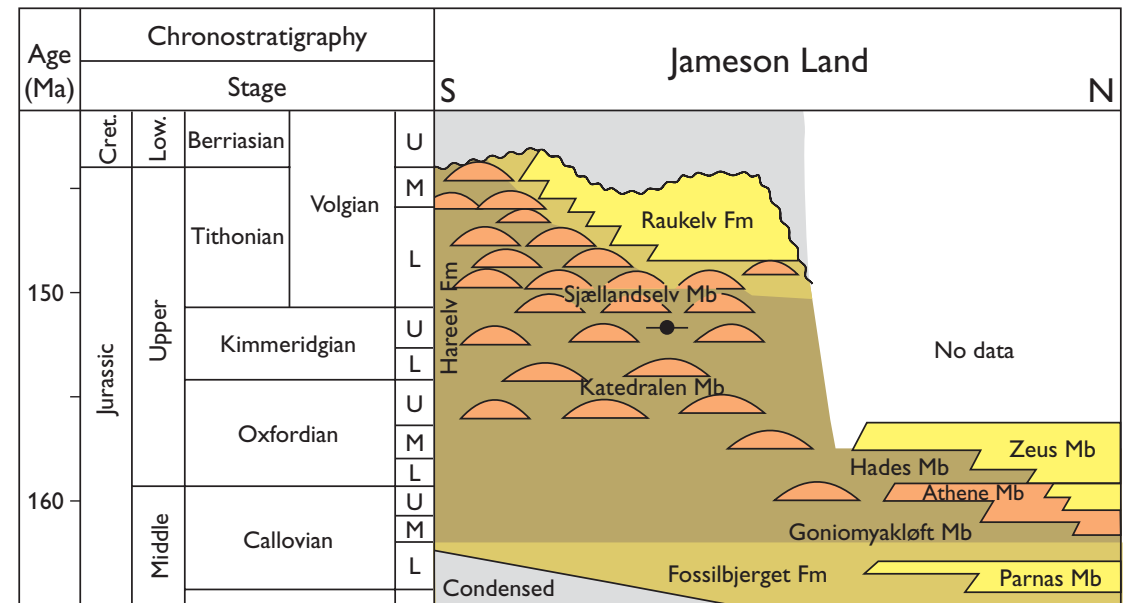

Shallow marine sandstones

Shelf transition-zone siltstones/heteroliths

Marine shelf/basinal mudstones

Deep marine sandstones

the most prolific source rock in the north Atlantic region (Fig. 2). The deepest and most central part of the Jameson Land Basin at Blokelv approximately $35 \mathrm{~km}$ west of Constable Pynt was chosen as the drill site (Fig. 1).

The Blokelv drilling (Fig. 3) produced high quality cores (GGU 511101) with a diameter of $5.6 \mathrm{~cm}$ and $99.3 \%$ recovery to a depth of $233.8 \mathrm{~m}$ (Fig. 4). The top part from 1.72 to $10.08 \mathrm{~m}$ recovered homogeneous medium to fine-grained sandstone with two thin shale intervals of the Sjællandselv Member (Hareelv Formation). The Katedralen Member (Hareelv Formation) from 10.08 to $233.8 \mathrm{~m}$ consists of alternating sandstone and shale units; the lower boundary of the member was not reached.

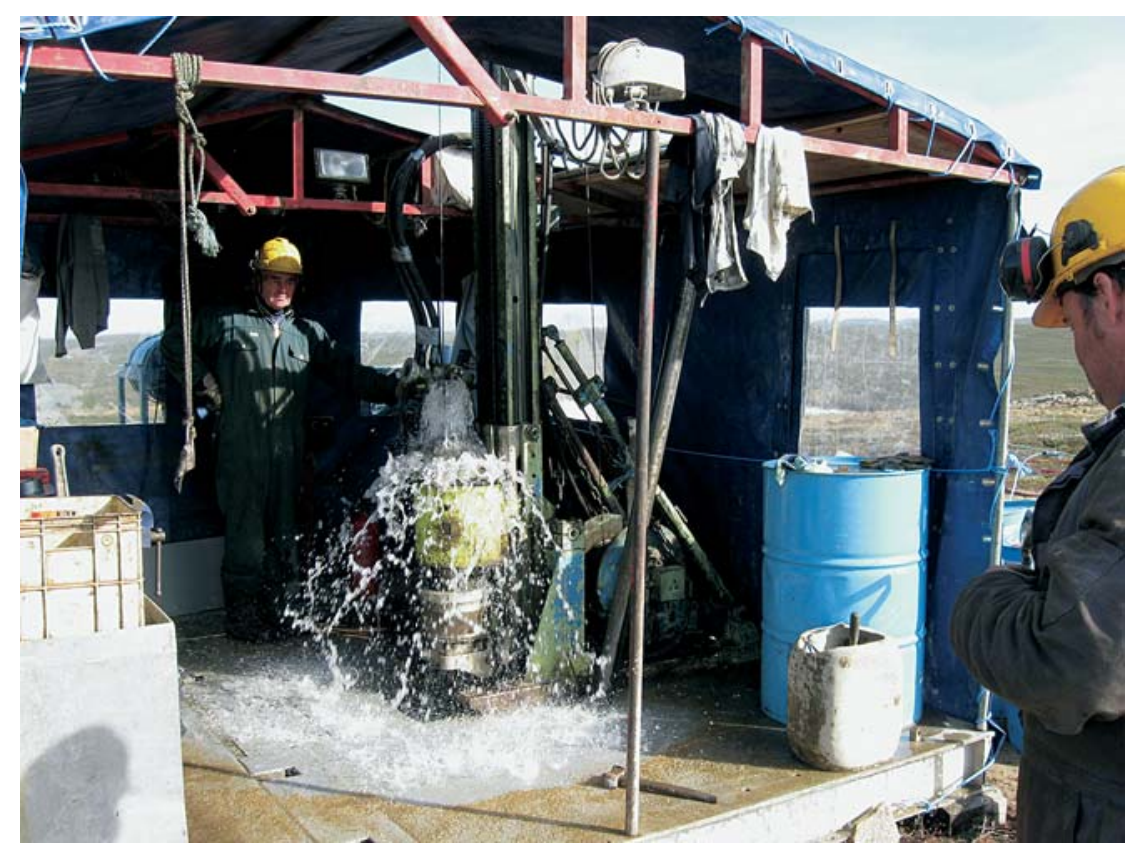

Fig. 2. Chrono- and lithostratigraphy of the Middle and Upper Jurassic in Jameson Land. Modified from Surlyk (2003).

Studies of the new cores from the Katedralen Member focus on the stratigraphy and age of the Hareelv Formation and lateral, contemporaneous deposits (Fig. 2). The lower boundary of the Katedralen Member is well known from the Ugleelv region and the west side of Hurry Inlet, where few, condensed beds of mudstone and finegrained sandstone separate the Fossilbjerget and Hareelv Formations. These beds are age equivalent to the Olympen Formation in central to northern Jameson Land (P. athleta to C. densiplicatum Chronozones of Late Callovian to Middle Oxfordian age; Larsen \& Surlyk 2003).

The deposition of laminated mudstone of the Katedralen Member began in the Late Oxfordian. The continued sedimentation of the Katedralen Member mud reaches into the Kimmeridgian and Volgian especially in eastern and southern Jameson Land (Fig. 2). During the Volgian, the coarsegrained sand of the Sjxllandselv Member and Raukelv Formation was deposited in the western and central parts of the Jameson Land Basin at the same time as the Katedralen Member mud was deposited in the easternmost, apparently much deeper basin (Surlyk 2003). The youngest parts of the Katedralen Member are only known from the locality Fortet near Constable Pynt in eastern Jameson Land, where the dinoflagellate assemblage indicates an age not older than latest Middle Volgian (Fig. 2).

The upper boundary of the Katedralen Member is located where laminated mudstone is replaced by homogeneous sandstone of the Sjællandselv Member. The sand slumped into the central basin from shelf-edge deltas prograding from north-west and west. This shift in deposition can be followed from west to east across the basin in a number of shallow core drillings and exposed

Fig 3. Drilling operations near Blokelv in Jameson Land. Three-metre-long cores are drilled at a time, and each time a core is retrieved water is pouring out of the drill hole. 
sections. The boundary is strongly diachronous: Kimmeridgian-Volgian in the west to Middle - Upper Volgian in the easternmost part of the basin.

An extensive analytical programme to evaluate source and reservoir rock properties to establish a high-resolution dinoflagellate cyst and macrofossil biostratigraphic zonation, and assess sedimentological, diagenetic and sequence stratigraphic aspects of the penetrated succession is in progress.

\section{Field work}

Field work took place by means of helicopter-supported field teams of 2-4 persons, operating primarily out of field camps. The activities covered a wide range of geological disciplines that are briefly described below. Field teams camped at or visited locations from Kap Dalton on the Blosseville Kyst in the south to Kuhn $\varnothing$ in the north (Fig. 1).

\section{Volcanology}

Volcanic rocks in the form of plateau basalts as well as various intrusions abound in East and North-East Greenland, and their histories of emplacement and mutual relationships are important elements in the understanding of the regional geology. A field team sampled and studied the youngest volcanic rocks in the region that are preserved in a small graben at Kap Dalton. Additional studies were undertaken on Hold with Hope and Wollaston Forland and on nearby islands east and north thereof. Samples collected from various outcrops will be subjected to chemical and petrological analyses as well as radiometric dating in order to establish their ages and mutual relationships.

\section{Petroleum source rocks and Cretaceous- Palaeogene stratigraphy}

Petroleum source rocks are known to be present in East and North-East Greenland in a number of stratigraphic intervals ranging in age from Middle Devonian to Upper Jurassic, whereas source rocks in younger units still remain to be demonstrated. Among these various units the Upper Jurassic 'Kimmeridge Clay equivalents' referred to as the Hareelv, Kap Leslie and Bernbjerg Formations (Surlyk 2003) must be considered the more important ones with respect to petroleum exploration. The documentation of spatial and temporal variations in petroleum potential within these units is crucial to the prediction of the distribution of the potential in the little-known offshore basins. Upper Jurassic shale of the Bernbjerg Formation was sampled on Hold with Hope and Wollaston Forland, and potential drill sites were found at Rødryggen and Brorson Halvø on Wollaston Forland. In addition, Cretaceous shale was sampled for both stratigraphic and geochemical purposes on Wollaston Forland, whereas sampling of Cretaceous deposits and drill-site identification on Hold with Hope had to be postponed due to the presence of polar bears in the area.

The stratigraphy and sedimentological development of the Cretaceous-Palaeogene succession of North-East Greenland have hitherto received relatively little attention, probably due to a general assumption that it was deposited during a period of tectonic quiescence with little change in overall basin configuration. During the field season in 2008, some effort was devoted to increasing our knowledge of the Cretaceous-Palaeogene development through sedimentological studies and stratigraphic sampling. Among the results was the discovery of a more than $150 \mathrm{~m}$ thick, unmapped succession of presumably Palaeogene sand with minor mud-

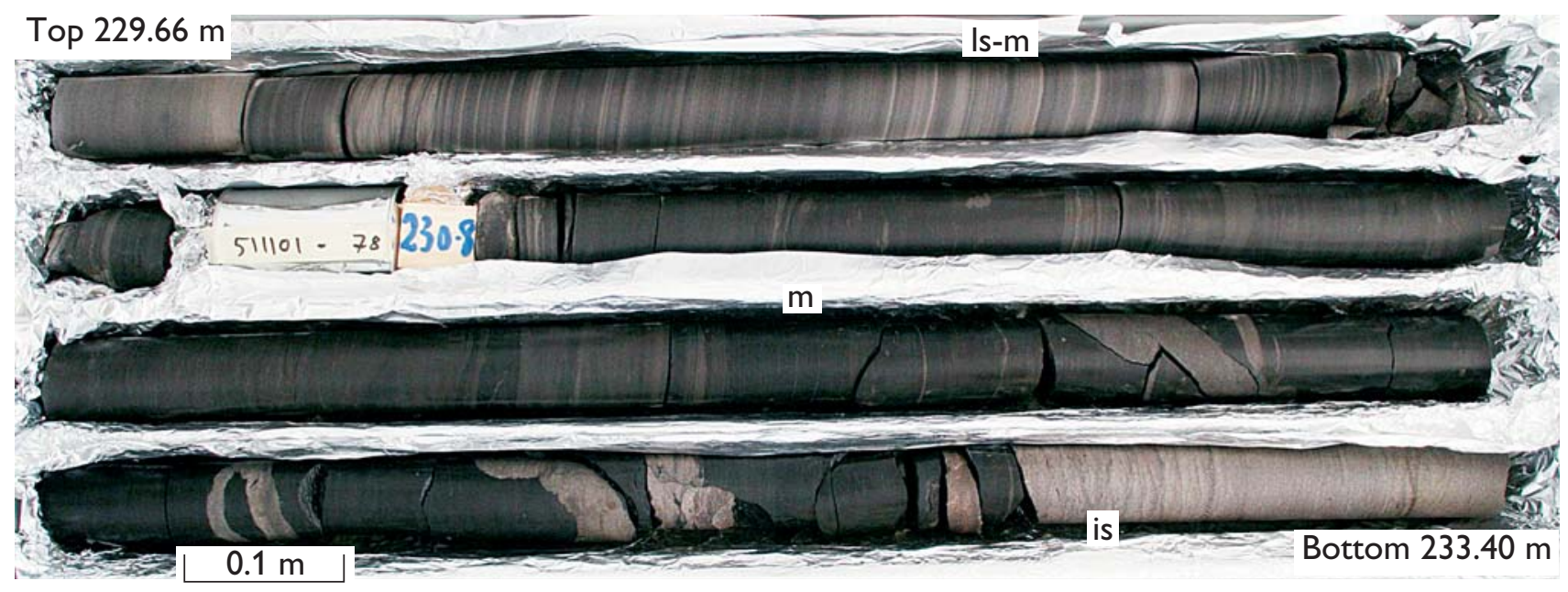

Fig. 4. Core box no. 62 with black organic rich mudstone (m), intrusive sandstone dykes (is), and laminated heterolithic sandstone-mudstone (ls-m) of the Katedralen Member, Hareelv Formation. The diameter of the core is $56 \mathrm{~mm}$. 
stones and coal directly underlying the plateau basalts on eastern Wollaston Forland. Sub-basaltic Palaeogene sand is reported from several localities in the region.

\section{Landscape analysis, uplift and sand provenance studies}

Burial and uplift are geological processes, the magnitude and timing of which are of utmost importance in petroleum geology. Assessment of these may be undertaken by a combination of methods, including large-scale landform analysis and apatite fission track analysis, which enable us to detect ancient erosion or peneplanisation surfaces as well as quantify palaeogeothermal gradients (Bonow et al. 2007). Moreover, identification of the source areas for sandy deposits through geological time is important to understand temporal dispersal patterns of sediment within the basin, and for correlation of sand units. Such provenance studies can be carried out by age determinations and detailed chemical analyses of provenance-sensitive minerals such as zircon and garnet. Since uplift and provenance studies to a large extent make use of the same type of sample material, two field teams collected samples for both purposes. Spot and profile samples were collected at a large number of locations from Milne Land and Jameson Land in the south to Wollaston Forland in the north.

\section{Seepage studies}

Experience from central West Greenland shows that when certain requirements are met petroleum seepages may be preserved in the lower parts of the Palaeogene basalt succession and in carbonate veins associated with dykes (BojesenKoefoed et al. 1999). The utility of the experience gained in West Greenland was tested in North-East Greenland, but with little success, since essentially no traces of petroleum were found in the volcanic rocks exposed in the region. A number of locations on Kuhn $\varnothing$ and Wollaston Forland were checked, but no hydrocarbons were found. The lavas are indeed very porous, but the level of thermal alteration indicated by the zeolite facies is too low, the volcanic rocks are too thin and healed carbonate-filled veins are nearly absent. Similar studies of the volcanic rocks on Hold with Hope were severely hampered by bad weather and polar bears, but since the geological conditions appear more favourable there and seepages have been recorded previously, further attempts should be made during future field work.

\section{Airborne stereo-photography}

Systematic stereo-photography is a valuable tool for largescale stratigraphy and structural geology (Dueholm \& Pedersen 1992). Nearly 2000 stereo-photographs were taken from a Partenavia aircraft during two sessions in (1) Jameson Land, Milne Land, Schuchert Dal, Kong Oscar Fjord, southern Traill $\varnothing$ region and (2) Kejser Franz Joseph Fjord, Gauss Halvø, Hudson Land, Gael Hamke Bugt, Home Forland and the south-eastern Hold with Hope region.

\section{Future activities in North-East Greenland}

The project described here is planned to continue for the next 4-5 years, with both field work and shallow core drilling starting in the south and gradually moving northwards. In addition, an excursion to the region for sponsoring oil companies is planned for 2010. In 2008, the Bureau of Minerals and Petroleum, Greenland, published a 'roadmap' for a future licensing round in North-East Greenland which, pending political approval, will lead to nomination and licensing rounds in 2011-2013. In order to meet the needs of the sponsors, further special studies may be undertaken in the forthcoming years.

\section{Acknowledgements}

The staff at the Sirius Sledge Patrol stations at Daneborg and Mestersvig and the staff at Constable Pynt airport are thanked for their practical assistance and hospitality.

\section{References}

Bojesen-Koefoed, J.A., Christiansen, F.G., Nytoft, H.P. \& Pedersen, A.K 1999: Oil seepage onshore West Greenland: evidence of multiple source rocks and oil mixing. In: Fleet, A.J. \& Boldy, S.A.R. (eds): Petroleum Geology of Northwest Europe: proceedings of the 5th conference, 305-314. London: Geological Society.

Bonow, J.M., Japsen, P., Green, P.F., Wilson, R.W., Chalmers, J.A., Klint, K.E.S., van Gool, J.A.M., Lidmar-Bergström, L. \& Pedersen, A.K. 2007: A multi-disciplinary study of Phanerozoic landscape development in West Greenland. Geological Survey of Denmark and Greenland Bulletin 13, 33-36.

Dueholm, K.S. \& Pedersen, A.K. (eds) 1992: Geological analysis and mapping using multi-model photogrammetry. Rapport Grønlands Geologiske Undersøgelse 156, $72 \mathrm{pp}$.

Larsen, M. \& Surlyk, F. 2003: Shelf-edge delta and slope deposition in the Upper Callovian - Middle Oxfordian Olympen Formation, East Greenland. In: Ineson, J.R. \& Surlyk, F. (eds): The Jurassic of Denmark and Greenland. Geological Survey of Denmark and Greenland Bulletin 1, 931-948.

Surlyk, F. 2003: The Jurassic of East Greenland: a sedimentary record of thermal subsidence, onset and culmination of rifting. In: Ineson, J.R. \& Surlyk, F. (eds): The Jurassic of Denmark and Greenland. Geological Survey of Denmark and Greenland Bulletin 1, 659-722. 